\title{
Cardamine occulta, the correct species name for invasive Asian plants previously classified as C. flexuosa, and its occurrence in Europe
}

\author{
Karol Marhold ${ }^{1,2}$, Marek Šlenker², Hiroshi Kudoh³, Judita Zozomová-Lihováa \\ I Department of Botany, Faculty of Science, Charles University, Benátská 2, CZ-128 01 Praha 2, Czech Republic \\ 2 Institute of Botany, Slovak Academy of Sciences, Dúbravská cesta 9, SK-845 23 Bratislava, Slovakia 3 Center \\ for Ecological Research, Kyoto University, Hirano 2-509-3, Otsu 520-2113, Japan
}

Corresponding author: Karol Marhold (karol.marhold@savba.sk)

Academic editor: P. de Lange | Received 21 January 2016 | Accepted 2 March 2016 | Published 25 March 2016

Citation: Marhold K, Šlenker M, Kudoh H, Zozomová-Lihová J (2016) Cardamine occulta, the correct species name for invasive Asian plants previously classified as C. flexuosa, and its occurrence in Europe. PhytoKeys 62: 57-72. doi: 10.3897/ phytokeys.62.7865

\begin{abstract}
The nomenclature of Eastern Asian populations traditionally assigned to Cardamine flexuosa has remained unresolved since 2006, when they were found to be distinct from the European species C. flexuosa. Apart from the informal designation "Asian C. flexuosa", this taxon has also been reported under the names $C$. flexuosa subsp. debilis or C. hamiltonii. Here we determine its correct species name to be C. occulta and present a nomenclatural survey of all relevant species names. A lectotype and epitype for C. occulta and a neotype for the illegitimate name $C$. debilis (replaced by C. flexuosa subsp. debilis and C. hamiltonii) are designated here. Cardamine occulta is a polyploid weed that most likely originated in Eastern Asia, but it has also been introduced to other continents, including Europe. Here data is presented on the first records of this invasive species in European countries. The first known record for Europe was made in Spain in 1993, and since then its occurrence has been reported from a number of European countries and regions as growing in irrigated anthropogenic habitats, such as paddy fields or flower beds, and exceptionally also in natural communities such as lake shores.
\end{abstract}

\section{Keywords}

Asian Cardamine flexuosa, Brassicaceae, Cardamine flexuosa subsp. debilis, Cardamine hamiltonii, Cardamine occulta, China, Cruciferae, Europe, invasive species, typification

Copyright Karol Marhold et al. This is an open access article distributed under the terms of the Creative Commons Attribution License (CC BY 4.0), which permits unrestricted use, distribution, and reproduction in any medium, provided the original author and source are credited. 


\section{Introduction}

Cardamine flexuosa (Cruciferae) was described by Withering (1796) from the locality "Rookery at Edgbaston" in England. Recently, this name was lectotypified by Post et al. (2009) by the illustration (Fascicle. 4, Table no. 48, alternatively numbered no. 277) in Curtis' Flora Londinensis or, plates and descriptions of such plants as grow wild in the environs of London (1781). Schulz (1903), in his monograph of the genus Cardamine, treated $C$. flexuosa in a wide sense with a number of subspecies, varieties and formas. Out of the infraspecific taxa recognized by Schulz (1903), C. scutata Thunb., C. fallax (O.E. Schulz) Nakai and C. pennsylvanica Willd. are now generally recognized as separate species. The remaining part of $C$. flexuosa had until recently been treated as a single species distributed worldwide without the recognition of any infraspecific taxa (Jalas and Suominen 1994, Zhou et al. 2001, Al-Shehbaz et al. 2006).

It was not until the phylogenetic paper by Lihová et al. (2006) that it was realized that European and Eastern Asian populations traditionally treated as C. flexuosa belong to two different taxa. Both DNA sequence and chromosome number data demonstrated that they represent two distinct evolutionary lineages. While the native European species C. flexuosa is tetraploid ( $2 \mathrm{n}=32$, Marhold 1994, Kučera et al. 2005), Eastern Asian plants, informally treated by Lihová et al. as "Asian C. Alexuosa", are octoploid $(2 \mathrm{n}=64$, Lihová et al. 2006, T. Mandáková, Brno, unpublished data, Marhold et al., unpublished data, contrary to the assumed hexaploid level based on flow-cytometric evidence by Bleeker et al. 2008). Multiple hypotheses about the parentage of tetraploid European C. flexuosa have been put forward, invoking both auto- and allopolyploidy (reviewed by Lihová et al. 2006 and Mandáková et al. 2014). Only recently, the cytogenetic approach (combining genomic in situ hybridization and comparative chromosome painting, $\mathrm{CCP} / \mathrm{GISH}$ ) provided unequivocal evidence that this taxon is an allopolyploid originating from the diploids $C$. amara L. and C. hirsuta L. (Mandáková et al. 2014). In turn, CCP/GISH (Mandáková et al., in prep.) revealed allopolyploidy also in Eastern Asian C. flexuosa (as inferred earlier from molecular data, Lihová et al. 2006), but with a different parentage. Three distinct diploid genomes were identified within this octoploid, corresponding to $C$. amara, C. parviflora L. (or perhaps their unknown close relatives) and another, as yet unidentified taxon.

Morphological characters of Eastern Asian populations treated as C. flexuosa and their differences from European populations are presented by a number of authors (e.g., Rosenbauer 2011, Hepenstrick and Hoffer-Massard 2014, Dirkse et al. 2015). Most of their descriptions, however, do not encompass the whole variation of the two taxa, and none consider differences from other Asian relatives, such as C. scutata, so a thorough morphometric study of $C$. flexuosa and related Eastern Asian taxa is required (Marhold et al. in prep.). These two taxa also show considerable differences in their ecological requirements. European C. flexuosa occurs mostly in forest plant communities along wet forest roads or in various open habitats and is only seldom found as a 
weed in flower beds (often introduced with mulch of bark chips) or in greenhouses (Kudoh et al. 2006). Eastern Asian C. flexuosa, by contrast, is primarily a weed of rice paddy fields, and perhaps only secondarily occurs in other open habitats (Kudoh et al. 1993, Yatsu et al. 2003). It was hypothesized by Lihová et al. (2006) that the origin and spread of this latter taxon are associated with the establishment of suitable manmade habitats (e.g. paddy fields). Based on morphology and molecular data, Lihová et al. (2006) reported Eastern Asian C. flexuosa from Japan, China, Taiwan, Thailand, Vietnam, Australia, Canada, USA and Mexico.

As a consequence, based on their genetic divergence, different ploidy, allopolyploid origins, morphology, ecological requirements and distribution patterns, we are of the opinion that European and Eastern Asian populations previously treated as $C$. flexuosa should be classified as two different taxa at the species level. The concept of two taxa is also adopted in the Flora of North America (Al-Shehbaz et al. 2010) and is followed by other authors reporting plants corresponding to Eastern Asian C. flexuosa from different parts of the world, particularly Europe. Several names have been used for this taxon, namely C. flexuosa subsp. debilis O.E. Schulz (e.g., Rankin Rodríguez and Greuter 2009, Lazzeri et al. 2013, Ardenghi and Mossini 2014, Hohla 2014a,b), C. hamiltonii G. Don (e.g., Bomble 2014, Ardenghi et al. 2015, Dirkse et al. 2015, Hohla 2015) [both replacement names based on illegitimate C. debilis D. Don (non C. debilis Banks ex DC.)] and C. occulta Hornem. (Klinkenberg 2015).

None of the above-mentioned names were properly typified or used unequivocally, which necessitated a thorough search for the correct species-level name for "Asian Cardamine flexuosa". Here we present a nomenclatural survey of all relevant names and highlight the increasing number of records of "Asian Cardamine flexuosa" across Europe.

\section{Materials and methods}

For the purpose of typifying names, herbarium specimens, especially types and authentic collections, were searched for in relevant herbaria (B, BM, C, E, KW, LINN, $\mathrm{P}, \mathrm{TI}$ and UPS), and protologues were studied in relevant publications. Bibliographical citations in databases, such as IPNI (The International Plant Names Index; www.ipni. org), Tropicos (www.tropicos.org) and The Plant List (www.theplantlist.org), were also checked, and for species, links to IPNI LSID metadata are provided. In cases when specimen images were available online, stable identifiers for specimens (Hyam et al. 2012, Güntsch and Hagedorn 2013, Hagedorn et al. 2013; herbaria B, SAV), other permanent links (herbarium P) or links via JSTOR Global Plants (https://plants.jstor. org/; herbarium KW) are provided. In designating types of names of taxa, we strictly followed the International Code of Nomenclature for algae, fungi, and plants (McNeill et al. 2012). We also surveyed all relevant literature sources and gathered the first records of "Asian C. flexuosa" in European countries and their larger administrative divisions. 


\section{Results and discussion}

\section{Nomenclature}

The type status of species names corresponding to "Asian C. flexuosa" in the sense of Lihová et al. (2006) has been determined, and justifications for their typifications are presented. Cardamine occulta is the oldest name applicable to populations of "Asian C. flexuosa".

Cardamine occulta Hornem., Suppl. Hort. Bot. Hafn.: 71. 1819 (urn:lsid:ipni. org:names:280533-1:1.2) 三 Cardamine flexuosa var. occulta (Hornem.) O.E.Schulz, Bot. Jahrb. Syst. 32: 479 (1903) (http://biodiversitylibrary.org/page/185332). Described from: "Hab. in China. C. intr. 1817". Lectotype (designated here, or perhaps holotype): Cardamine occulta mihi, sponte provenit in terra e China al[1]ata, ex h. b. Hafn. Hornemann s.n. - C! (ex herb. Hornemann, C10021749). Epitype (designated here): China, Zhejiang Province, Linhai County, Kuocang Mountains (括苍 山), ditch along the road, $28^{\circ} 50.35^{\prime} \mathrm{N} ; 120^{\circ} 58.90^{\prime} \mathrm{E}, 79 \mathrm{~m}, 18$ April 2014, K. Marhold CH18/12/2014, Yunpeng Zhao 赵云鹏, \& Ming Jiang 蒋明 - SAV! (SAV0006529 [http://ibot.sav.sk/herbarium/object/SAV0006529]).

There is a single specimen available in herbarium C originating from Hornemann's collection that undoubtedly represents the single remnant of the original material for the name C. occulta. As Hornemann (1819) referred to the specimen in the garden and not to the herbarium sheet, and as we cannot exclude that there was originally more than one specimen of this taxon in his collection, we designate the specimen as a lectotype of the name $C$. occulta (admitting that the specimen might well represent the holotype). The plant on the type herbarium sheet was apparently grown from seeds at the Copenhagen Botanical Garden ("ex h[ortus] b[botanicus] Hafn[iensis]"). Perhaps cultivation at the garden might be the reason why the specimen cannot be reliably and unequivocally identified as "Asian C. flexuosa" for the purposes of the precise application of the name $C$. occulta to this taxon (especially considering the occurrence of a number of closely related taxa in China; Zhou et al. 2001). Therefore, in order to fix the application of the name $C$. occulta, we designate here an epitype of this name from a cytogenetically investigated population from Eastern China with a known chromosome number ( $2 \mathrm{n}=64$; Mandáková et al., in prep.).

= Cardamine debilis D. Don, Prodr. Fl. Nepal. 201. 1825 [26 Jan-1 Feb 1825], (urn:lsid:ipni.org:names:280260-1:1.3; http://biodiversitylibrary.org/page/393098), nom illeg., non Banks ex DC. Syst. Nat. 2: 265. 1821 [late May 1821] (urn:lsid:ipni. org:names:280259-1:1.4; http://biodiversitylibrary.org/page/39512107). Described from: "Hab. in Nepaliâ ad Narainhetty. Hamilton." Neotype (designated here): [India, West Bengal] Botanical Garden Darjeeling, weed, 18. 6. 1959, Lövkvist C-3363 - UPS! (GUID UPS:BOT:V-194865) 三 C. hamiltonii G. Don, Gen. Hist. 1: 167. 1831 [early Aug 1831] (urn:lsid:ipni.org:names:280357-1:1.2.2.1.1.1; http:// 
biodiversitylibrary.org/page/389972) 三 C. flexuosa subsp. debilis O.E. Schulz, Bot. Jahrb. Syst. 32: 478. 1903 (http://biodiversitylibrary.org/page/185331).

The name $C$. debilis D. Don is based on data in the manuscript of Francis $\mathrm{Bu}$ chanan-Hamilton (referred to as "Hamilton MSS"; Don 1825: 201), and it is unclear whether D. Don studied any specimen collected by Buchanan-Hamilton. Although Hara and Williams (1979) mentioned the type of $C$. debilis [when indicating localities of C. scutata subsp. flexuosa (With.) Hara in Nepal], in Shrestha and Press (2000), the type specimen is listed as "not found". In any case, a thorough search in the herbaria BM, E, LINN-Smith (Roy Vickery, John Edmondson, Mark Watson, personal communication) did not reveal any original material of this name. There is a specimen corresponding to the description of $C$. debilis D. Don and to "Asian C. flexuosa", collected in the neighbouring area of West Bengal, with a chromosome number counted by B. Lövkvist ( $2 n=64$, unpublished data, deposited at UPS). This specimen is selected here as a neotype to fix the application of the name.

= Cardamine brachycarpa Franch., Bull. Soc. Bot. France 26: 83. 1879, nom. illeg. (urn:lsid:ipni.org:names:280196-1:1.4; http://biodiversitylibrary.org/page/260368), non Opiz, Naturalientausch 11: 411.1826 (urn:lsid:ipni.org:names:280195-1:1.3). Described from: [JAPAN] "Insul. Nippon, prov. Etchigo, circa Niigata, secus vias humidas (R. P. Faurie)". Lectotype (designated by Marhold et al. 2015: 11): [JAPAN, Prefecture Niigata], "Nippon, Niigata, secus vias, [U. J.] Faurie 23" - P! (P00747512 [http:// coldb.mnhn.fr/catalognumber/mnhn/p/p00747512]); Isolectotype - P! (P00747513 [http:/coldb.mnhn.fr/catalognumber/mnhn/p/p00747513]) 三 C. koshiensis Koidz., Fl. Symb. Orient.-Asiat. 43. 1930 (urn:Isid:ipni.org:names:280422-1:1.2.1.2).

= Cardamine arisanensis Hayata, Icon. Pl. Formosan. 3: 20. 1913 [25 Dec 1913] (urn:lsid:ipni.org:names:280161-1:1.3). Described from: "In Monte Morrison, ad 10000-11000 ped. alt., leg. T.Kawakami et U.Mori, 1906, Oct. (No.2252); in Montibus Centralibus, Feb. 1908”. Lectotype (Ohwi 1934: 50, see also Al-Shehbaz and Peng 2000: 237): [TAIWAN] "Kagi, Arisan (Chiayi, Alishan), Taiwan Sotoku-fu, Industry Bureau, Plant Specimens, no. 3631, 25 March 1908, T. Kawakami \& S. Mori s.n.” (TI) 三 Barbarea arisanense (Hayata) S.S.Ying, Alp. Pl. Taiwan in Color 2: 170. 1978.

= Cardamine autumnalis Koidz. Bot. Mag. (Tokyo) 43: 404.1929 (urn:lsid:ipni. org:names:280169-1:1.3) - Described from: "Nippon: Yokosuka (1g. Wichura, Oct. 18, 1860) Mus. Bot. Berol.-Dahlem”. Holotype: “Japan, Jokohama, 19. [sic!] 10. 1860, [M. E.] Wichura 1064 [1069?]” B! (B 100241388 [http://herbarium.bgbm.org/ object/B100241388]).

The species $C$. autumnalis was described with a reference to "Cardamine flexuosa ssp. debilis Schultz (pro. parte) in Engl. Bot. Jahrb. 32. (1903) s. 479, (quoad specim. ex Yokoska)". Indeed, there is a specimen marked "Japonia: ... pr. Jokohama leg. Wichura 1860" referred to by Schulz (1903: 479) as Cardamine flexuosa subsp. 
debilis deposited in B. The specimen bears a revision label by Schulz with the name "Cardamine flexuosa With. subspec. debilis Don var. occulta (Hornem.) O. E. Sch.", dated 25. 4. 1902. Although this specimen was identified by Schulz as var. occulta, it should be noted that there is no specimen referred to by Schulz (1903: 480) identified as Cardamine flexuosa subsp. debilis var. occulta from Japan.

The usual life cycle of C. occulta in Eastern Asian rice fields includes flowering in early spring before rice is planted and the fields are flooded by water. Nevertheless, there are also exceptions such as the nomenclatural type of the name $C$. autumnalis, which represents an autumn-flowering plant of C. occulta. Kudoh et al. (1993: fig. 8) reported such plants from paddy fields in the autumns of years in which rice was not cultivated (no water flooding during summer).

- Cardamine aff. flexuosa sensu I. Thomps., Flora of Victoria 3: 434-442. 1996.

There are two other names at the species level that are potentially applicable to "Asian C. flexuosa", namely:

Cardamine nasturtioides D.Don, Prodr. Fl. Nepal.: 201. 1825. [26 Jan-1 Feb 1825] (urn:lsid:ipni.org:names:280509-1:1.3; http://biodiversitylibrary.org/ page/393098) - Described from: "Hab. in Nepaliâ. Hamilton."

Cardamine decurrens (Blume) Zoll. et Moritzi in Moritzi, Syst. Verz.: 35. 1846 (urn:lsid:ipni.org:names:280262-1:1.3.2.2; http://reader.digitale-sammlungen. de/de/fs1/object/display/bsb10302557_00051.html) $\equiv$ Pteroneurum decurrens Blume, Bijdr. Fl. Ned. Ind. 2: 51.1825 [12 Jun-2 Jul 1825] (urn:lsid:ipni. org:names:288262-1:1.1.2.2.1.2; http://biodiversitylibrary.org/page/428177). Described from: "in altis paludosis montis Burangrang Provinciae Krawang."

The location of the original material of these two names is as yet unknown, and it remains to be ascertained whether they are synonyms of $C$. occulta or represent other taxa. In any case, both these names are later than $C$. occulta, which has priority among all species names applicable to "Asian C. Alexuosa".

The name $C$. zollingeri Turcz. was sometimes considered to be a synonym of $C$. flexuosa in a wide sense (e.g., Zhou et al. 2001, Al-Shehbaz et al. 2006, Al-Shehbaz and Watson 2012) or of C. flexuosa subsp. debilis (Schulz 1903: 479). Nevertheless, it is morphologically different from both $C$. flexuosa and C. occulta in the circumscriptions presented here and likely represents a separate taxon that requires further study:

Cardamine zollingeri Turcz., Bull. Soc. Imp. Naturalistes Moscou 27(2): 294. 1854 (urn:lsid:ipni.org:names:280762-1:1.3) 三NasturtiumobliquumZoll.\&Moritzi,Natuur- Geneesk. Arch. Ned.-Indië 2: 580.1845 (urn:lsid:ipni.org:names:287528-1:1.4; https://archive.org/stream/natuurengeneesku02bata\#page/580/mode/2up) - Described from: "[Java] Nasturtium obliquum Z. et M. Herb. N. 2211 ... Legi in 
arenosis et glareosis vulcanicis ad fluviorum ripas e. g. prope Trawas prov. Modjokerto VIII.1844. p. m. 3000' s. m." Lectotype (designated here): [INDONESIA, Java], "Planta Javanica a cl. Zolliger lecta no. 2211" Zollinger 2211 KW! (KW001000851 [https://plants.jstor.org/stable/10.5555/al.ap.specimen.kw001000851]); Isolectotype: P! (P00747614 [http://coldb.mnhn.fr/catalognumber/mnhn/p/p00747614]).

\section{Occurrence of Cardamine occulta in Europe}

Cardamine occulta most likely originated in Eastern Asia. It is unclear whether it naturally occurs or ever occurred in any natural plant community. The localities that we know from Japan and Eastern China and which are referred to on herbarium specimens represent solely man-made habitats, most often rice paddies, orchards or various other kinds of synanthropic vegetation. This is why we (Lihová et al. 2006) hypothesized that the origin and spread of this polyploid species might have been connected with the occurrence of man-made habitats.

As stated above, Lihová et al. (2006) reported plants corresponding to C. occulta from Japan, China, Taiwan, Thailand, Vietnam, Australia, Canada, USA and Mexico. Other previously published data corresponding to $C$. occulta than those that were referred to by Lihová et al. (2006) were the report of $C$. debilis D. Don from North America as an introduced weed (Rollins 1993) and C. aff. flexuosa from Australia (Thompson 1996). Subsequently, this taxon was published also for Cuba (Rankin Rodríguez and Greuter 2009, as C. flexuosa subsp. debilis).

When Lihová et al. (2006) suggested that European and Asian C. flexuosa should be treated as separate taxa, no record corresponding to Asian C. flexuosa plants was known from the European territory. Nevertheless, a number of records from Europe have been published since 2007, and we can trace the spreading of this invasive plant throughout the continent (see Table 1, Fig. 1). To the best of our knowledge, the earliest record of C. occulta from Europe dates back to 1993, when this species was collected in the Spanish province of Alicante and originally identified as C. flexuosa. Its true taxonomic identity was, however, clarified much later (Crespo et al. 2013). In 2007 the first author of this paper received for identification a specimen collected in 2003 in a rice field ditch in the province of Piedmont, Italy (Vercelli, Arborio) by Michel Desfayes (Fully, Switzerland). This specimen undoubtedly belongs to $C$. occulta and might have been introduced together with rice from Eastern Asia. From the same broad locality, the occurrence of this taxon was reported by Thomas Götz (a specimen collected in 2005, published by Dienst 2007) and more recently by Verloove and Ardenghi (2015; as C. hamiltonii).

The third spot in Europe where C. occulta was reported from are the shores of Lake Constance (Bodensee) in Germany. In spring 2004, an unknown Cardamine species was detected there at the Reichenau dam (observed by W. Ostendorp, M. Dienst and E. Klein; Dienst 2007). The identity of these plants was confirmed by DNA sequenc- 


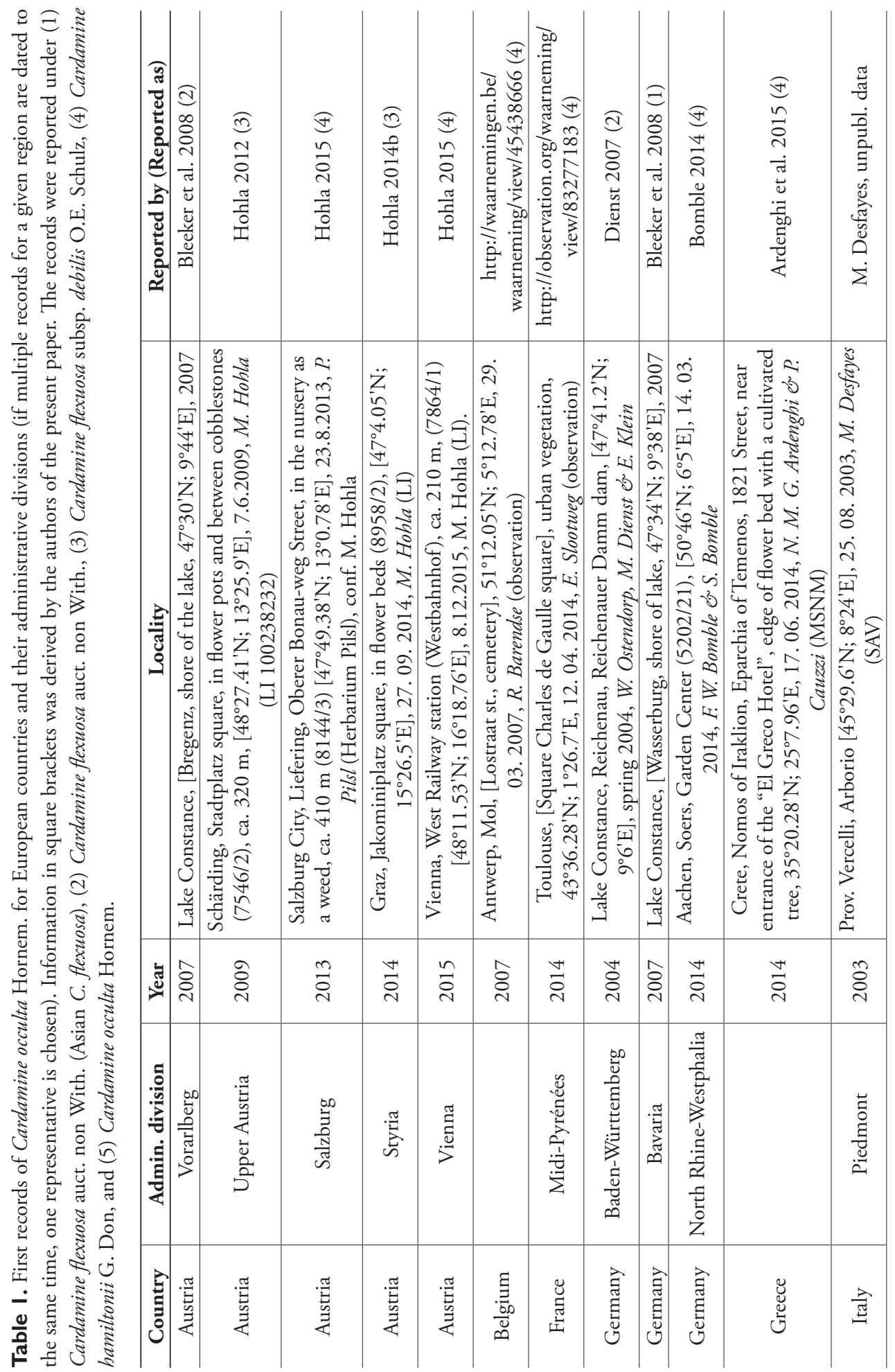


Cardamine occulta, the correct species name for invasive Asian plants...

\begin{tabular}{|c|c|c|c|c|c|c|c|c|c|c|c|}
\hline 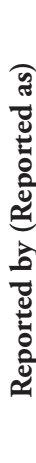 & 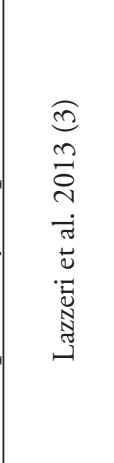 & 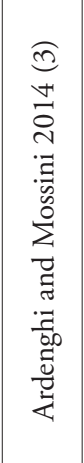 & 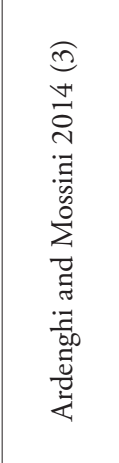 & 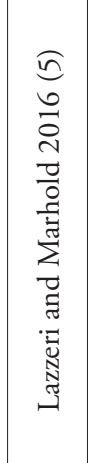 & 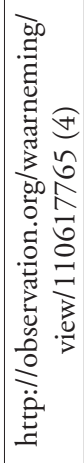 & 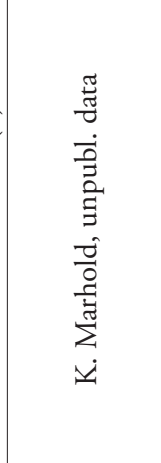 & 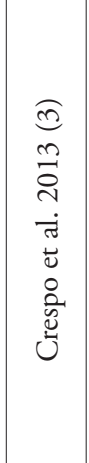 & 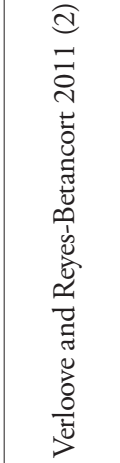 & 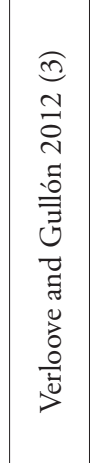 & $\begin{array}{l}\widehat{0} \\
m \\
0 \\
0 \\
0 \\
0 \\
0 \\
0 \\
0 \\
\end{array}$ & 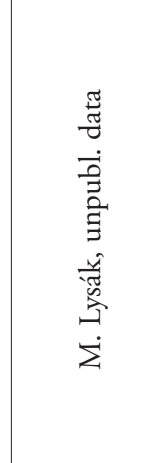 \\
\hline & 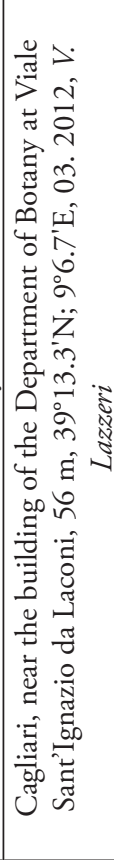 & 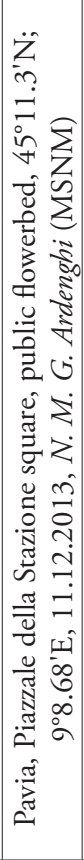 & 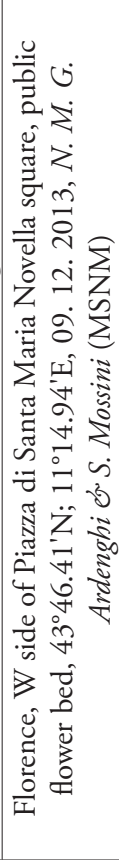 & 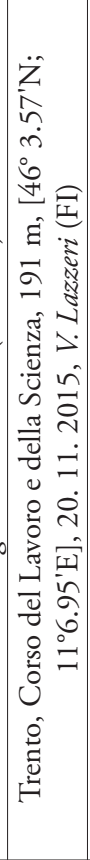 & 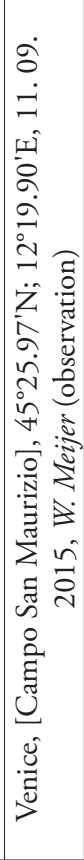 & 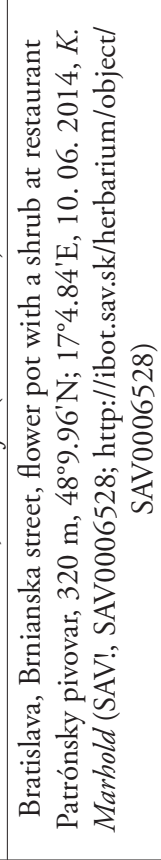 & 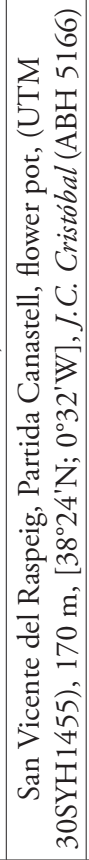 & 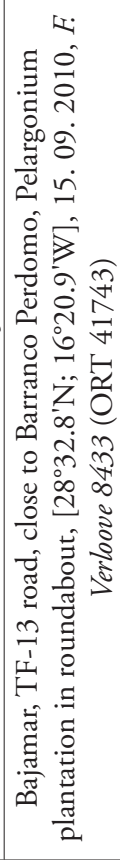 & 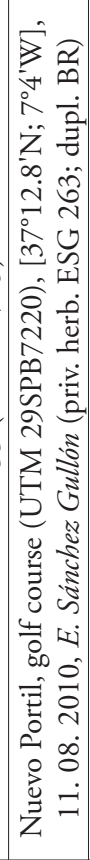 & 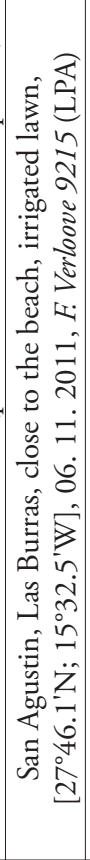 & 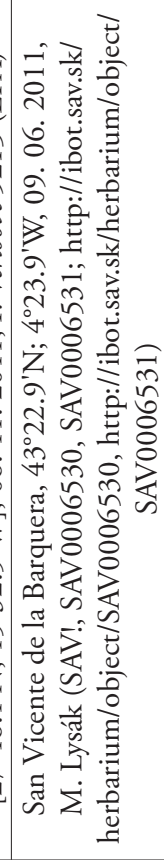 \\
\hline હ্ّ & 울 & 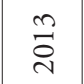 & $\stackrel{m}{\stackrel{n}{c}}$ & $\stackrel{n}{\stackrel{n}{n}}$ & 후 & 호 & $\stackrel{\approx}{\Omega}$ & 움 & $\stackrel{\circ}{\stackrel{0}{0}}$ & 完 & 。্ \\
\hline 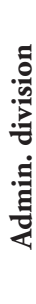 & 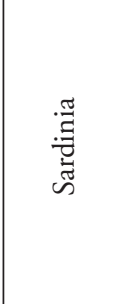 & 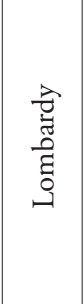 & 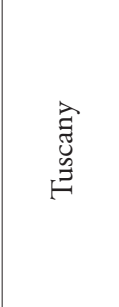 & 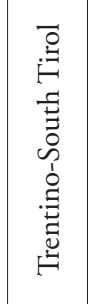 & 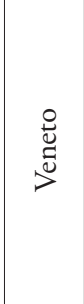 & & 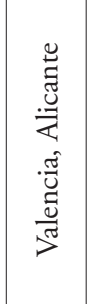 & 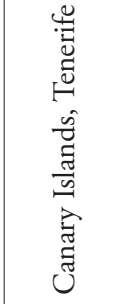 & 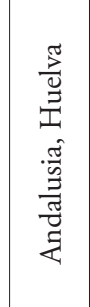 & 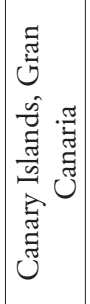 & 节 \\
\hline & ت્తี & త్ & 土 & 焉 & స్తే & $\frac{\frac{\pi}{n}}{\frac{0}{n}}$ & مै & क्चี & कै & คี & $\begin{array}{l}\tilde{\tilde{n}} \\
\text { के }\end{array}$ \\
\hline
\end{tabular}




\begin{tabular}{|c|c|c|c|c|c|c|c|c|c|}
\hline 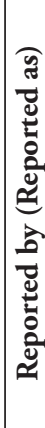 & 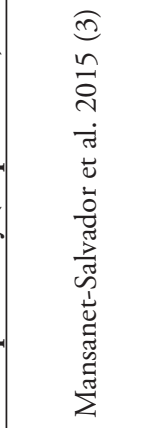 & 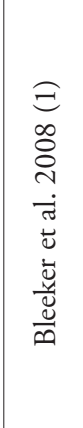 & 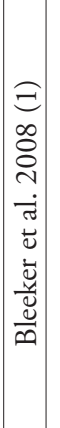 & 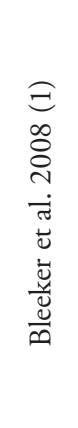 & 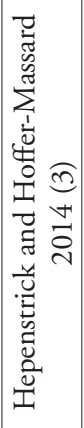 & 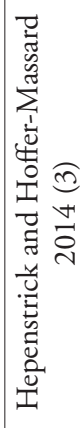 & 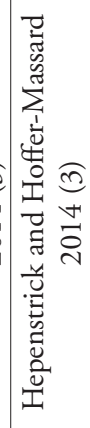 & 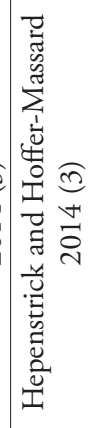 & 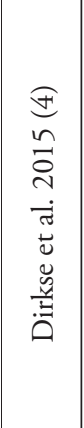 \\
\hline శู & 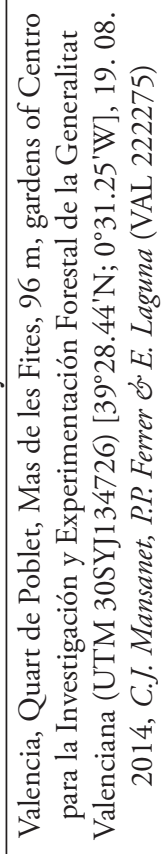 & 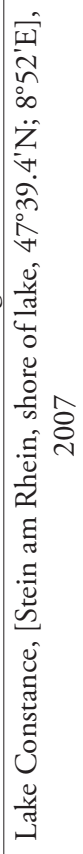 & 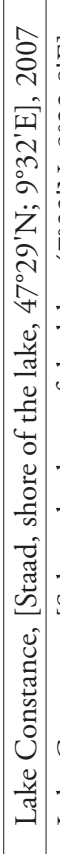 & 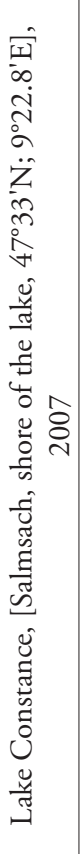 & 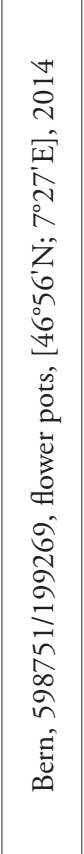 & 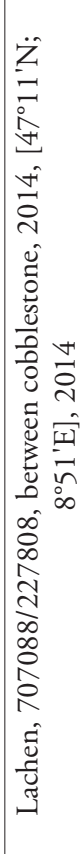 & 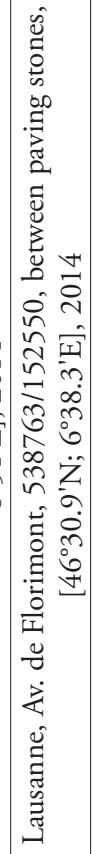 & 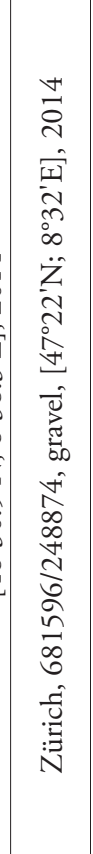 & 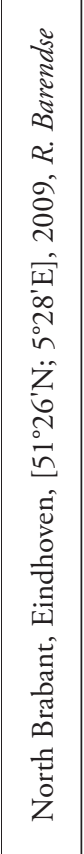 \\
\hline$\underset{\beth}{\beth}$ & $\underset{\sim}{\stackrel{\Delta}{*}}$ & 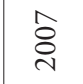 & 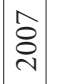 & $\stackrel{\hat{\sigma}}{\circ}$ & $\underset{\sim}{\stackrel{\Delta}{*}}$ & $\underset{\sim}{\stackrel{H}{\sim}}$ & $\underset{d}{\stackrel{d}{d}}$ & $\underset{\sim}{\stackrel{*}{d}}$ & \\
\hline 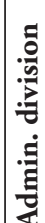 & 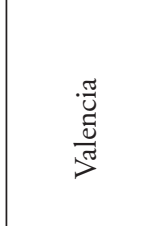 & 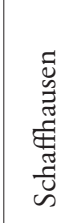 & 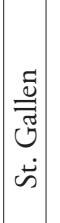 & 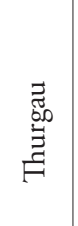 & 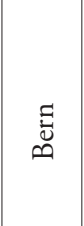 & $\frac{\sum_{\tilde{S}}}{\tilde{\omega}}$ & 晃 & 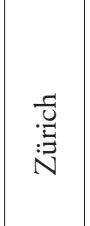 & \\
\hline ن & के & 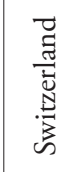 & 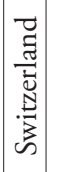 & 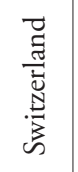 & 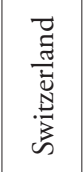 & 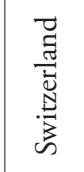 & 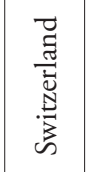 & 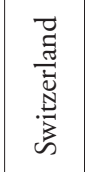 & 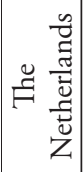 \\
\hline
\end{tabular}




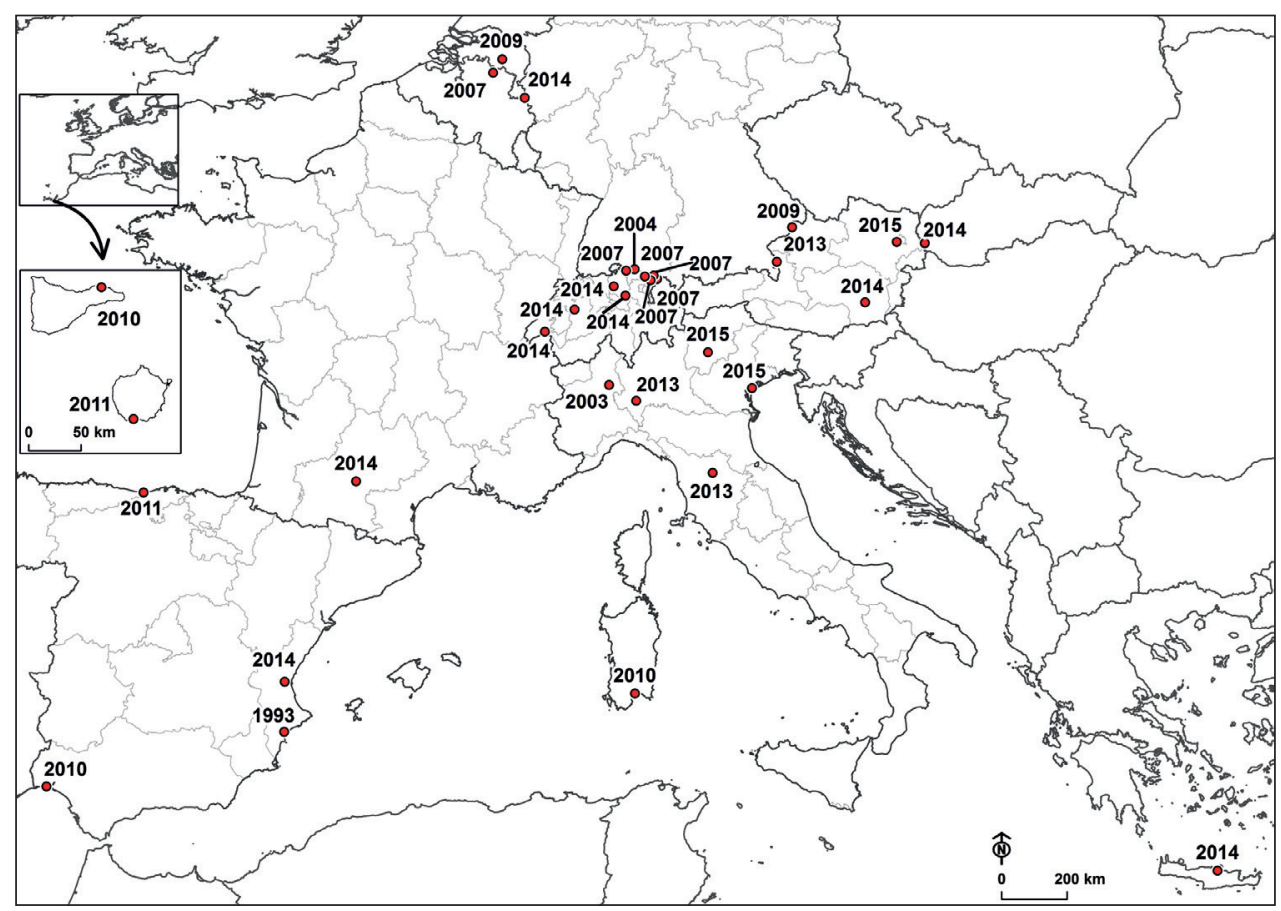

Figure I. Localities of the first occurrences of Cardamine occulta Hornem. for European countries and their administrative divisions. The year of the first occurrence at each locality is given. The inset shows Tenerife and Gran Canaria of the Canary Islands.

ing (Bleeker et al. 2008). Until 2007, 95 locations on the shores of Lake Constance had been known. Localities were found around the lake in Germany (Baden-Württemberg and Bavaria), Austria (Vorarlberg) and Switzerland (cantons Schaffhausen, Thurgau, and St. Gallen; Bleeker et al. 2008). Bleeker et al. (2008) noted that C. occulta was more frequent on fine-grained and nutrient-rich sediments than on nutrientpoor gravel shores. It is likely that this species may change the community structure of ephemeral vegetation on bare and organic sediments.

Cardamine occulta was later reported also from continental Spain, the Canary Islands, France, parts of Germany, Switzerland and Austria other than the shores of Lake Constance, from Belgium, the Netherlands, Slovakia, and Crete (Table 1). It is nevertheless likely that the species is currently present, but still overlooked, also in other European countries. It should be noted that most records mentioned in Table 1 refer to urban vegetation. Cardamine occulta grows in flower beds and pots, at the edges of roads, among cobblestones or paving stones, or on pavements, often in irrigated places. In most cases, it was apparently introduced as a weed, often with mulch, from plant nurseries where it finds appropriate growing conditions (as reported from North America by Post et al. 2011). However, the species was also found in rice fields in northern Italy, where it was most likely introduced with rice from Eastern Asia. 
There are only a few known occurrences of $C$. occulta in European natural plant communities, and it seems that such reports are restricted to the surroundings of Lake Constance. Bleeker et al. (2008) hypothesized that this species might have been introduced to the lake from rice fields of northern Italy by migrating birds or directly from Japan by tourists.

For most of the countries and administrative divisions presented in Table 1, only one or few localities of $C$. occulta are known. There are numerous observational records of C. occulta from the Netherlands and Belgium in the databases presented at observation.org, waarneming.nl and waarnemingen.be (referred to as $C$. hamiltonii), perhaps because botanists in these countries were encouraged to searched for it. Nevertheless, there are no voucher specimens documenting these data, and some of them are not even documented by photographs. According to the photographic documentation, some records are apparently based on misidentifications of $C$. hirsuta and tetraploid C. flexuosa. A number of photographic records document juvenile plants that are hard to identify reliably. For future mapping of the distribution of $C$. occulta, all records should be documented by vouchers deposited in public herbaria.

It is apparent that, unlike European C. flexuosa, C. occulta represents an invasive species that is quickly spreading from its area of origin in Eastern Asia to other continents. The characteristics of seed dormancy and germination of $C$. occulta are likely to enhance its invasiveness, especially in wet and occasionally submerged habitats. It has been reported that seeds of C. occulta can survive both in dry and submerged conditions for more than three months (Yatsu et al. 2003). The combination of seed dormancy in dry soil and dormancy release by submergence (Yatsu et al. 2003) is likely to enhance the transportation of C. occulta seeds with soils and the establishment of invasive populations in seasonally submerged habitats such as paddy field, dams or lake shores and in regularly irrigated flower beds and other urban habitats. Diploid $C$. hirsuta is in fact another example of the invasive potential of Cardamine species. This species originated in Europe and is now widely distributed on all continents, particularly in drier conditions. The speed of its spreading can be illustrated on the example of the Japanese archipelago. While the first record of this species for Japan dates to 1974 (Kudoh et al. 1992), already in 2006 it became a common roadside weed across most of Honshu Island, the main island of Japan, and was spreading also to Kyushu and Hokkaido Islands (Yatsu et al. 2003, Kudoh et al. 2007).

\section{Acknowledgements}

This work was supported by the Czech Science Foundation (P506/12/0668 to K.M.). The authors thank Dušan Senko, Bratislava for his help with the map and two reviewers for their constructive comments. 


\section{References}

Al-Shehbaz IA, Arai K, Ohba H (2006) Cardamine. In: Iwatsuki K, Boufford DE, Ohba H (Eds) Flora of Japan, vol. IIa, Angiospermae, Dicotyledoneae, Archichlamydeae(a). Kodansha Ltd., Tokyo, 482-490.

Al-Shehbaz IA, Marhold K, Lihová J (2010) Cardamine Linnaeus. In: Flora of North America Editorial Committee (Ed.) Flora of North America North of Mexico, vol. 7. Oxford University Press, New York \& Oxford, 464-484.

Al-Shehbaz IA, Peng ChI (2000) The genus Barbarea (Brassicaceae) in Taiwan. Botanical Bulletin of Academia Sinica 41: 237-242. http://ejournal.sinica.edu.tw/bbas/content/2000/3/ bot13-10.html

Al-Shehbaz IA, Watson MF (2012) Flora of Nepal. Cruciferae. Webedition 1. http://data.rbge. org.uk/publications/FloraofNepal/library/Cruciferae/1 [accessed 5. 12. 2015]

Ardenghi NMG, Cauzzi P, Galasso G (2015) Cardamine hamiltonii G. Don. In: von RaabStraube E, Raus T (Eds) Euro+Med-Checklist Notulae, 4. Willdenowia 45: 121-122. doi: $10.3372 /$ wi.45.45113

Ardenghi NMG, Mossini S (2014) Cardamine flexuosa subsp. debilis O. E. Schulz. In: von Raab-Straube E, Raus T (Eds) Euro+Med-Checklist Notulae, 3. Willdenowia 44: 292. doi: $10.3372 /$ wi.44.44211

Bleeker W, Klausmeyer S, Peintinger M, Dienst M (2008) DNA sequences identify invasive alien Cardamine at Lake Constance. Biological Conservation 141: 692-698. doi: 10.1016/j. biocon.2007.12.015

Bomble FW (2014) Japanisches Reisfeld-Schaumkraut (Cardamine hamiltonii) in Aachen. [Japanese rice field Bitter-cress (Cardamine hamiltonii) in Aachen (North Rhine-Westphalia, Germany)]. Veröffentlichungen des Bochumer Botanischen Vereins 6: 1-5. http:// nbn-resolving.de/urn/resolver.pl?urn:nbn:de:hebis:30:3-354651

Crespo MB, Azorín MM, Camuñas E (2013) Novedades corológicas para la flora valenciana [New records for the flora of the Valencian Community (E of Spain)]. Flora Montiberica 55: 118-127. http://hdl.handle.net/10045/33135

Curtis W (1781) Flora Londinensis: or Plates and Descriptions of Such Plants as Grow Wild in the Environs of London, vol. 2, fascicle 4, number 38. London.

Dienst M (2007) Cardamine-Neophyt im Bodensee-Litoral - wer kennt weitere Fundorte? http://www.wildblumen.net/BAS/module/wordpress/?p=52 [accessed 11.12.2015]

Dirkse GM, Zonneveld BJM, Duistermaat LH (2015) Cardamine hamiltonii G. Don - Aziatische veldkers (Brassicaceae) in Nederland. Gorteria 47: 64-69.

Don D (1825) Prodromus florae Nepalensis : sive Enumeratio vegetabilium quae in itinere per Nepaliam proprie dictam et regiones conterminas, ann. 1802-1803. Detexit atque legit $d$. d. Franciscus Hamilton, (olim Buchanan) Accedunt plantae a. d. Wallich nuperius missae. J. Gale, London, 1-256.

Güntsch A, Hagedorn G (2013) Stable identifiers for specimens - A CETAF ISTC initiative supported by pro-iBiosphere. http://www.pro-ibiosphere.eu/news/4296_stable\%20identifiers $\% 20$ for $\% 20$ specimens $\% 20-\% 20$ a $\% 20$ cetaf $\% 20$ istc $\% 20$ initiative $\% 20$ supported $\% 20$ by\%20pro-ibiosphere/ [accessed 11.12.2015] 
Hagedorn G, Catapano T, Güntsch A, Mietchen D, Endresen D, Sierra S, Groom Q, Biserkov J, Glöckler F, Morris R (2013) Best practices for stable URIs. http://wiki.pro-ibiosphere. eu/wiki/Best_practices_for_stable_URIs [accessed 11.12.2015]

Hara H, Williams LHJ (1979) An Enumeration of the Flowering Plants of Nepal, vol. 2. British Museum (Natural History), London, 1-220.

Hepenstrick D, Hoffer-Massard F (2014) Un xénophyte asiatique du groupe Cardamine flexuosa: identification, nomenclature et génétique. Bulletin du Cercle vaudois de botanique 43: 69-76. http://pd.zhaw.ch/publikation/upload/207561.pdf

Hohla M (2012) Bromus sitchensis - neu für Österreich, Plantago coronopus - neu für Oberösterreich sowie weitere Beiträge zur Kenntnis der Flora des Innviertels. Stapfia 97: 180-192. http://www.zobodat.at/pdf/STAPFIA_0097_0180-0192.pdf

Hohla M (2014a) Beiträge zur Kenntnis der Flora von Bayern IV. Berichte der Bayerischen Botanischen Gesellschaft zur Erforschung der heimischen Flora 84: 91-100.

Hohla M (2014b) Hystrix patula - neu für Österreich, sowie weitere Beiträge zur Flora von Oberösterreich, Salzburg, Steiermark und Vorarlberg. Stapfia 101: 83-100.

Hohla M, Diewald W, Király G (2015) Limonium gmelini - eine Steppenpflanze an österreichischen Autobahnen sowie weitere Neuigkeiten zur Flora Österreichs. Stapfia 103: 127-150. http://www.zobodat.at/pdf/STAPFIA_0103_0127-0150.pdf

Hornemann JW (1819) Supplementum Horti botanici hafniensis. Typis Schultzii, Hafniae, $1-172$.

Hyam RD, Drinkwater RE, Harris DJ (2012) Stable citations for herbarium specimens on the internet: an illustration from a taxonomic revision of Duboscia (Malvaceae). Phytotaxa 73: 17-30. doi: 10.11646/phytotaxa.73.1.4

Jalas J, Suominen J (Eds) (1994) Atlas Florae Europaeae. Distribution of Vascular Plants in Europe, vol. 10. Committee for Mapping the Flora of Europe and Societas Biologica Fennica Vanamo, Helsinki, 1-224.

Klinkenberg B (Ed.) (2015) E-Flora BC: Electronic Atlas of the Flora of British Columbia [eflora.bc.ca]. Lab for Advanced Spatial Analysis, Department of Geography, University of British Columbia, Vancouver, http://ibis.geog.ubc.ca/biodiversity/eflora/ [accessed 03.12.2015]

Kučera J, Valko I, Marhold K (2005) On-line database of the chromosome numbers of the genus Cardamine (Brassicaceae). Biologia 60: 473-476. http://www.cardamine.sav.sk/www/index. php?lang=en

Kudoh H, Ishiguri Y, Kawano S (1992) Cardamine hirsuta L., a new ruderal species introduced into Japan. Journal of Phytogeography and Taxonomy 40: 85-89.

Kudoh H, Ishiguri Y, Kawano S (1993) Phenotypic variability in life history traits and phenology of field populations of Cardamine flexuosa and C. fallax (Cruciferae) in Honshu, Japan. Plant Species Biology 8: 7-20. doi: 10.1111/j.1442-1984.1993.tb00229.x

Kudoh H, Marhold K, Lihová J (2006) Notes on Cardamine impatiens L., C. flexuosa With., C. hirsuta L. and C. parviflora L. in Japan. Bunrui 6: 41-49.

Kudoh H, Nakayama M, Lihová J, Marhold K (2007) Does invasion involve alternation of germination requirements? A comparative study between native and introduced strains of an annual Brassicaceae, Cardamine hirsuta. Ecological Research 22: 869-875. doi: 10.1007/ s11284-007-0417-5 
Lazzeri V, Marhold K (2016) Cardamine occulta Hornem. (Brassicaceae). In: Galasso G, Domina G, Adorni M, Alessandrini A, Ardenghi NMG, Banfi W, Bedini G, Bertolli A, Brundu G, Calbi M, Cecchi L, Cibei C, D’Antraccoli M, De Bastiani A, Faggi G, Ghillani L, Giardini M, Iberite M, Kleih M, Latini M, Lazzeri V, Liguori P, Marhold K, Masin R, Mauri S, Meneguzzo E, Mereu G, Nicolella G, Olivieri N, Peccenini S, Perrino EV, Peruzzi L, Petraglia A, Pierini B, Prosser F, Roma-Marzio F, Romani E, Sammartino F, Selvaggi A, Signorile G, Stinca A, Verloove F, Nepi Ch. Notulae to the Italian Alien Vascular Flora 1. The Italian Botanist 1, in press.

Lazzeri V, Mascia F, Sammartino F, Campus G, Caredda A, Carlesi V, Fois M, Gestri G, Mannocci M, Mazzoncini V, Lombraña AC, Santinelli M (2013) Novità floristiche per le regioni Sardegna e Toscana. Acta Plantarum Notes 2: 42-59. http://www.actaplantarum. org/ap_notes/pubbl/ActaPlantarum_Notes_2_dicembre_2013.pdf

Lihová J, Marhold K, Kudoh H, Koch MA (2006) Worldwide phylogeny and biogeography of Cardamine flexuosa (Brassicaceae) and its relatives. American Journal of Botany 93: 1206-1221. doi: 10.3732/ajb.93.8.1206

Mandáková T, Marhold K, Lysak MA (2014) The widespread crucifer species Cardamine flexuosa is an allotetraploid with a conserved subgenomic structure. New Phytologist 201: 982-992. doi: 10.1111/nph.12567

Mansanet-Salvador CJ, Ferrer-Gallego PP, Ferrando I, Laguna E (2015) Notas sobre el complejo taxonómico Cardamine flexuosa With. (Cruciferae) y su presencia en la Comunidad Valenciana. Flora Montiberica 59: 72-82. http://dialnet.unirioja.es/servlet/ oaiart? codigo $=5123731$

Marhold K (1994) Chromosome numbers of the genus Cardamine L. (Cruciferae) in the Carpathians and Pannonia. Phyton (Horn, Austria) 34: 19-34. http://www.zobodat.at/stable/ pdf/PHY_34_1_0019-0034.pdf

Marhold K, Kempa M, Al-Shehbaz I (2015) Lectotypification of names of Himalayan Brassicaceae taxa currently placed in the genus Cardamine. PhytoKeys 50: 9-23. doi: 10.3897/ phytokeys. 50.5080

McNeill J, Barrie FR, Buck WR, Demoulin V, Greuter W, Hawksworth DL, Herendeen PS, Knapp S, Marhold K, Prado J, Prud'homme van Reine WF, Smith GF, Wiersema JH, Turland NJ (2012) International Code of Nomenclature for Algae, Fungi, and Plants (Melbourne Code). Adopted by the Eighteenth International Botanical Congress Melbourne, Australia, July 2011 [Regnum Vegetabile 154]. Koeltz Scientific Books, Königstein, 240 pp.

Moritzi A (1845-1846) Systematisches Verzeichniss der von H. Zollinger in den Jahren 1842 1844 auf Java gesammelten Pflanzen, nebst einer kurzen Beschreibung der neuen Gattungen und Arten. Druck von Fr. X. Zepfel, Solothurn, i-xii + 1-144.

Ohwi J (1934) Plantae novae Japonicae. Repertorium Specierum Novarum Regni Vegetabilis 36: 39-58.

Post AR, Krings A, Xiang QY, Sosinski BR, Neal JC (2009) Lectotypification of Cardamine flexuosa (Brassicaceae). Journal of the Botanical Research Institute of Texas 3: 227-230. http://www.jstor.org/stable/41972157

Post AR, Ali R, Krings A, Xiang J, Sosinski BR, Neal JC (2011) On the identity of the Weedy Bittercresses (Cardamine: Brassicaceae) in United States nurseries: Evidence from molecules and morphology. Weed Science 59: 123-135. doi: 10.1614/WS-D-10-00063.1

Rankin Rodríguez R, Greuter W (2009) Brassicaceae. In: Greuter W, Rankin Rodríguez R (Eds) Flora de la República de Cuba, serie A, Plantas Vasculares, Fascículo 15. AR Gantner Verlag KG, Ruggell, 1-51. 
Rollins RC (1993) The Cruciferae of Continental North America. Stanford University Press, Stanford, $996 \mathrm{pp}$.

Rosenbauer A (2011) Ausgewählte Cardamine-Arten in Baden-Württemberg. Zentralstelle für die floristische Kartierung von Baden-Württemberg, Rosenstein, 1 p. http://www.flora. naturkundemuseum-bw.de/BestimmungCardamine.pdf

Schulz OE (1903) Monographie der Gattung Cardamine. Botanische Jahrbücher für Systematik, Pflanzengeschichte und Pflanzengeographie 32: 280-623.

Shrestha KK, Press JR (2000) Catalogue of Type Specimens from Nepal. Natural History Museum, London, 123 pp.

Thompson IR (1996) Cardamine. In: Walsh NG, Entwisle TJ (Eds) Flora of Victoria, vol. 3. Inkata Press, Melbourne, 434-442.

Verloove F (2013) New xenophytes from Gran Canaria (Canary Islands, Spain), with emphasis on naturalized and (potentially) invasive species. Collectanea Botanica 32: 59-82. doi: 10.3989/collectbot.2013.v32.006

Verloove F, Ardenghi NMG (2015) New distributional records of non-native vascular plants in northern Italy. Natural History Sciences. Atti della Societa Italiana di Scienze Naturali e del Museo Civico di Storia Naturale di Milano 2: 5-14. doi: 10.4081/nhs.2015.219

Verloove F, Gullón ES (2012) New records of interesting vascular plants (mainly xenophytes) in the Iberian Peninsula. II. Flora Mediterranea 22: 5-24. doi: 10.7320/FlMedit22.005

Verloove F, Reyes-Betancort JA (2011) Additions to the flora of Tenerife (Canary Islands, Spain). Collectanea Botanica 30: 63-78. doi: 10.3989/collectbot.2011.v30.007

Withering W (1796) An Arrangement of British Plants, vol. 3. Ed. 3. M. Swiney, Birmingham, 513-920.

Zhou TY, Lu LL, Yang G, Al-Shehbaz IA (2001) Brassicaceae. In: Wu ZY, Raven PH (Eds) Flora of China, vol. 8. Science Press \& Missouri Botanical Garden Press, Beijing \& St. Louis, 1-193.

Yatsu Y, Kachi N, Kudoh H (2003) Ecological distribution and phenology of an invasive species, Cardamine hirsuta L., and its native counterpart, Cardamine flexuosa With., in central Japan. Plant Species Biology 18: 35-42. doi: 10.1046/j.1442-1984.2003.00086.x 